\title{
The Influences of Economic Risk, Interest Rate and Exchange Rate on Non Oil Export and Its Implication on Gross Domestic Product in Indonesia Using SmartPLS
}

\author{
Arkas Viddy*, Besse Asniwati \\ Business Administration Department \\ Politeknik Negeri Samarinda (Polnes) \\ Samarinda, Indonesia \\ *viddy.arkas@yahoo.com, Besse317@gmail.com
}

\author{
Rafiqoh Rafiqoh \\ Accounting Department \\ Politeknik Negeri Samarinda (Polnes) \\ Samarinda, Indonesia \\ fiqopolnes@yahoo.com
}

\begin{abstract}
The research objectives are to create and to analyze the influence of exogenous variable such as economic risk, interest rate, and exchange rate on Indonesian none oil export and its implications for Indonesian economic growth. There are several variables are used such as economic risk, interest rates, and exchange rates as independent variables, while none oil exports and gross domestic product as dependent variables; the time series data will be taken from 1999 to 2018 . The structural model path analysis is used and Partial Least Square software (SmartPLS) is used for analyzing the data. The results proved that the economic risk, interest rate, and exchange rate have significant influence on and non oil export. Another result is economic risk, exchange rate, exports have significant influence on gross domestic product in Indonesia.
\end{abstract}

Keywords: economic risk, interest rate, exchange rate, export, gross domestic product

\section{INTRODUCTION}

For achieving economic development, plenty of economic variables need to be considered before taking any economic policies. For taking economic decision, economic risk, inflation and exchange rate are the most important exogenous variables usually need to be examined.

Gross Domestic Product (GDP) reflected the economic growth, GDP, real GDP growth, annual inflation rate, budget balance, and current account contributed the economic risk.

Economic risk is contributed by Gross Domestic Product (GDP) per capita, real GDP growth, annual inflation rate, budget balance, and current account/GDP. Since the level of economic risk is higher, it could lead negative effect on GDP because of increasing of government debt. It is noted by World Bank (2018) that Indonesian debt US\$ 298 billion in 2018. That is why Indonesia is on number $30^{\text {th }}$ of the countries that has the highest number of external debt. It is supported by Choong that an increase in foreign debt level adversely influences economic performance, whereas the decline in the rate of economic growth weakens the ability of the country to service its debt [1].
The economic activities depend of interest rate and exchange rate and it could lead the fluctuation of export and through economic growth. Interest rate and exchange rate effect on export and economic growth [2].

It is noted that economic risk showed slightly increased from 20.1 in 1999 to 35.8 in 2018 or economic risk condition experienced improving. Interest rate showed extremely decreased from 23.44 percent in 1999 to be 7.5 in 2018, while Rupiah exchange rate was extremely fluctuated from Rp 8,543.42 in 1999 and depreciated to $\mathrm{Rp} 10,386.17$ in 2009 while in 2011 Rupiah appreciated to Rp 8,773.25 and then radically decreased to be Rp 14,267.33 in 2018. (BPS, 2019). It is indicated that Indonesian faced uncertainty economic condition, whereas in one side the economic risk showed slightly improved, and interest rate either, while in other side the Rupiah showed radically depreciated. It is predicted that all of those factors impact on none oil export and Indonesian economic growth.

Based on the above condition, it is interesting to examine the effects of economic risk, interest rate and exchange rate on none oil export and its implication on gross domestic product in Indonesia.

Economic risk one of the determinant of none oil export. Country risk or uncertainty including political risk, economic risk and exchange risk have significant effects on none oil export and GDP [3-5]

The risk such as interest rate risk has significant effect on gross domestic product [6], while Fixler argued that economic risk (macro financial risk) including financial risk and economic risk have significant affected on GDP [7].

Export is the activities to sell product (goods and services) to others countries [8], while Mankiw stated that export is all of production goods and service in domestic for selling in abroad [9].

According to GDP is sums the "value added" at each stage of production, where value added is defined as total sales minus the value of intermediate inputs into the production 
Caption

production approach) or the value of purchases made by final users (expenditure approach) or sums the incomes generated by production (income approach) [10].

The impact of export or none oil export was examined by Mehrara, Firouzjaee and $\mathrm{Xu}$ that export growth and GDP growth have causality relationship $[11,12]$.

\section{Methods}

This study was to analyze the effects exogenous variables on the endogenous variables, so the formulation can be developed as follows:

$$
\begin{aligned}
& \mathrm{Y} 1=\alpha 1 \mathrm{X} 1+\alpha 2 \mathrm{X} 2+\alpha 3 \mathrm{X} 3+\alpha 4 \mathrm{X} 4+€ 1 \\
& \mathrm{Y} 2=\partial 1 \mathrm{X} 1+\partial 2 \mathrm{X} 2+\partial 3 \mathrm{X} 3+\partial 4 \mathrm{X} 4+\partial 5 \mathrm{Y} 1+\mu 1
\end{aligned}
$$

This formulation can be reduced to be:

$$
\begin{aligned}
\mathrm{Y} 1 & =\log \alpha 1 \mathrm{X} 1+\log \alpha 2 \mathrm{X} 2+\log \alpha 3 \mathrm{X} 3+\log \alpha 4 \mathrm{X} 4+€ 1 \\
\mathrm{Y} 2 & =\log \partial 1 \mathrm{X} 1+\log \partial 2 \mathrm{X} 2+\log \partial 3 \mathrm{X} 3+\log \partial 4 \mathrm{X} 4+\partial \log 5 \mathrm{Y} 1
\end{aligned}
$$

Whereas:

$$
\begin{aligned}
& € 1=\text { error term of } \mathrm{Y} 1 \\
& \mu 1=\text { error term of } \mathrm{Y} 2 \\
& \mathrm{X} 1=\text { Indonesian economic risk } \\
& \mathrm{X} 2=\text { Interest rate risk } \\
& \mathrm{X} 3=\text { Exchange rate risk } \\
& \mathrm{Y} 1=\text { Indonesian none oil export } \\
& \mathrm{Y} 2=\text { Indonesian GDP }
\end{aligned}
$$

The formulation could be solved by path analyzing by using the Structural Equation Model SmartPLS. This statistic analysis is used because of several reason such as: time series data less than 30, intervening variable part of the research model, data are not normal data. Classic Assumption Test is not necessary to be used analyzing the data because SmartPLS using Covariance Approach. The steps of analysis as below:

1) Designing the structural inner model

2) Constructing a path diagram

3) Converting a path diagram to regressions

4) Hypothesis parameter

5) Examining the hypothesis

Based on all variables were built, the research model can be figured as follows:

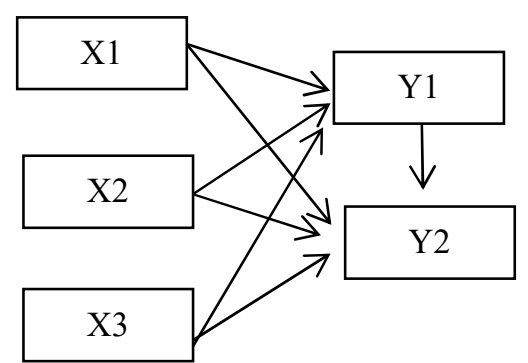

Fig. 1. Research structural model.
$\mathrm{X} 1=$ economic risk,

$\mathrm{X} 2$ = interest rate risk

$\mathrm{X} 3$ = exchange rate risk

Y1 = none oil export

Y2 $=$ Gross Domestic Product

From Figure 1, it can be explained that $\mathrm{X} 1, \mathrm{X} 2$, and $\mathrm{X} 3$ have direct influence on $\mathrm{Y} 1$, and $\mathrm{X} 1, \mathrm{X} 2, \mathrm{X} 3$ and $\mathrm{Y} 1$ have direct influence on $\mathrm{Y} 2$ and then the hypothesis are built are There is a significant effect between:

1) economic risk and none oil export;

2) interest rate and none oil export;

3) exchange rate and none oil export;

4) economic risk and GDP

5) interest rate and GDP

6) exchange rate and GDP

7) none oil export and GDP

\section{RESULTS AND DISCUSSIONS}

Using SmartPLS to analyze the data series, the first step is building the structural model and then captured as follows:

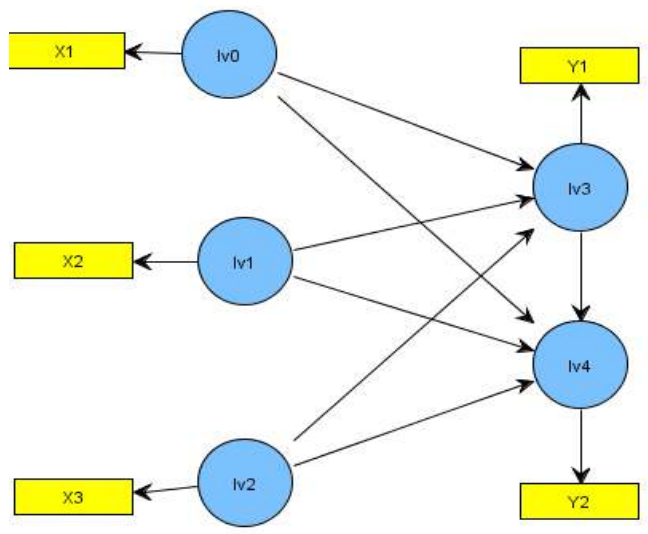

Fig. 2. Structural equation inner model.

After making connecting among variables, and defining all of variables as exogenous, intervening or as endogenous variables using SmartPLS, calculating and bootstrapping need to be done and the Structural Equation Inner Model can be seen as follows: 


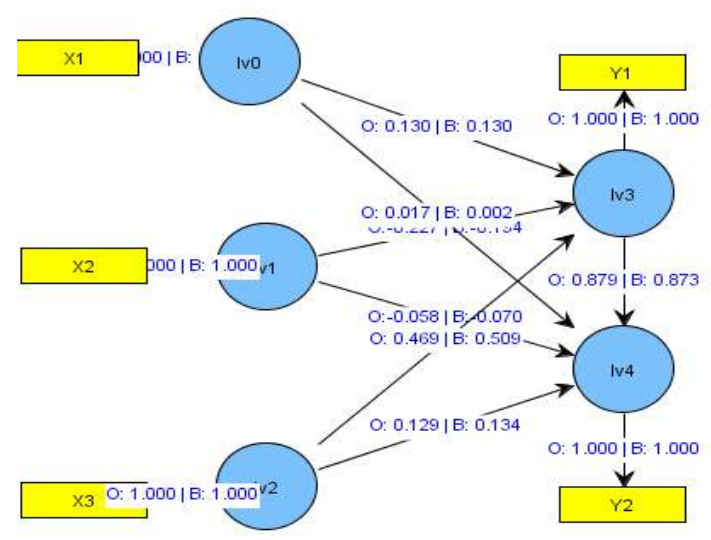

Fig. 3. Structural equation.

After undertaking statistical analysis, it was found the estimated results as exhibit at Table I as follows:

TABLE I. SMARTPLS BOOTSRAPPING RESULTS

\begin{tabular}{|l|l|l|l|l|}
\hline & $\begin{array}{c}\text { Original } \\
\text { sample } \\
\text { estimate }\end{array}$ & $\begin{array}{c}\text { Mean of } \\
\text { subsamples }\end{array}$ & $\begin{array}{c}\text { Standard } \\
\text { deviation }\end{array}$ & T-statistic \\
\hline Lv0 -> lv3 & 0.130 & 0.280 & 0.247 & 0.527 \\
\hline Lv1 -> lv3 & -0.227 & -0.087 & 0.262 & 0.868 \\
\hline Lv2 -> lv3 & 0.469 & 0.421 & 0.112 & 4.179 \\
\hline Lv0 -> lv4 & 0.017 & 0.017 & 0.030 & 0.583 \\
\hline Lv1 -> lv4 & -0.058 & -0.055 & 0.030 & 1.959 \\
\hline Lv2 -> lv4 & 0.129 & 0.128 & 0.018 & 7.228 \\
\hline Lv3 -> lv4 & 0.879 & 0.883 & 0.018 & 47.994 \\
\hline
\end{tabular}

Source: Data processed.

Based on the statistical analyzing result, it is examined that there are 5 estimating coefficients are positive, meanwhile only 2 estimating coefficients are negative. Interest rate risk variable is the only variable has negative effect, the estimating coefficient needs to be converted to the regression formulation as follows:

$$
\begin{aligned}
& \mathrm{Y} 1=0.130 \mathrm{X} 1-0.227 \mathrm{X} 2+0.469 \mathrm{X} 3 \\
& \mathrm{Y} 2=0.017 \mathrm{X} 1-0.058 \mathrm{X} 2+0.129 \mathrm{X} 3+0,879 \mathrm{Y} 1
\end{aligned}
$$

Based on above path equation, it was examined that the highest coefficient estimator is exchange rate, and then followed by interest rate (negative), and economic risk respectively for formulation (1), while based on formulation (2) none oil export is the highest estimator coefficient and followed by exchange rate, interest rate (negative) and economic risk respectively.

After examining the influences of exogenous variables on intervening and endogenous variable with the parameters used is the T Test with two tail test, which Level of confidence is $95 \%$ or $\alpha=0.05$, Degree of freedom is $n-k=19-5=14$ When $\mathrm{T}$ test $>\mathrm{T}$ table, so Ho rejected and $\mathrm{Hi}$ accepted, $\mathrm{T}$ Table $(\alpha=0,025, \mathrm{n}-\mathrm{k}=14)=1.796$

It could be decided that there are 3 hypotheses are accepted, and 4 hypotheses are rejected.
It is proved that hypothesis 3; exchange rate has significant effect on none oil export is accepted, hypothesis 6; exchange rate has significant effect on GDP and hypothesis 7; none oil export has significant effect on GDP is accepted.

On the contrary, that hypothesis 1; economic risk has significant effect on none oil export, hypothesis 2 ; interest rate has significant effect on none oil export, hypothesis 4; economic risk has significant effect on GDP, hypothesis 5; interest rate has significant effect on GDP are rejected

The effect of exchange rate on none oil export is positive significant. It means that since the Rupiah depreciated, the none oil export increase or when value of Rupiah decreased, the export price is also decreased because all export commodities will be paid by US dollar currency. That is caused when rupiah depreciated, it will be followed by increased of export commodities demand. It also occurred on the effect between exchange rate and GDP is positive significant. It means that when the rupiah felt down, all of export commodities price is decrease and the income and GDP increased. Similarly, that none oil export has significant effect on GDP which means since none oil export higher, the exporter income also higher or GDP increased. It was examined that in Indonesia exchange rate is the most powerful factor in stimulating both none oil export and GDP. This study supported the research undertaking by Cushman, Fang and Thompson, Le and Zak, Mehrara and Firouzjaee and Xu [3$5,12]$.

In conversely, economic risk, interest rate have not significant effect on none oil export and GDP. It means that economic risk and interest contributed too small effects on both none oil export and GDP, because during the last 20 years the rate of economic risk slightly increased (improved) while and interest rate slightly decreased (also improved). Even though economic risk contributed positive effect, while interest rate contributed negative effect, but both of their effects can be ignored. This study reversed to the research undertaking by Hall and Sargent, Fixler and Zieschang and Mehrara and Firouzjaee and $\mathrm{Xu}[6,7,11,12]$.

\section{CONCLUSION AND RECOMMENDATION}

It could be concluded that exchange rate has positive significant effect on none oil export and GDP, and none oil export also have significant influence on Indonesian GDP. On the contrary, it also could be concluded that economic risk, interest rate have no significant effect on none oil export and GDP.

Based on all of the conclusions, government should focus to maintain the value of Rupiah. It is also recommended that exporting company anticipate the Rupiah exchange rate fluctuation by hedging program.

\section{REFERENCES}

[1] C.K. Choong, E. Lau, V.K. Liew, C.H. Puah, "Does debts foster economic growth? The experience of Malaysia." African Journal of Business Management 4(8): 1564-1575. 2010.

[2] I. Arslan and S. Van Wijnbergen. "Export incentives, exchange rate policy and export growth in Turkey." The review of Economics and Statistics: 128-133. 1993. 
[8] N. Andelisa, "Analisis Daya Saing dan Aliran Ekspor Produk Crude Coconut Oil (CCO) Indonesia.[Skripsi]." Bogor. Institut Pertanian Bogor. 2011.

[3] D.O. Cushman, "The effects of real exchange rate risk on international trade." Journal of international Economics 15(1-2): 45-63. 1983.

[4] W.S. Fang and H. Thompson, "Exchange rate risk and export revenue in Taiwan." Pacific Economic Review 9(2): 117-129. 2004.

[5] Q.V. Le and P.J. Zak, "Political risk and capital flight." Journal of International Money and Finance 25(2): 308-329. 2006.

[6] G.J. Hall and T.J. Sargent, "Interest rate risk and other determinants of post-WWII US government debt/GDP dynamics." American Economic Journal: Macroeconomics 3(3): 192-214. 2011.

[7] D. Fixler and K. Zieschang, Deconstructing FISIM: should financial risk affect GDP? Communication à la $31 \mathrm{e}$ conférence générale de l'International Association for Research in Income and Wealth, SanktGallen (Suisse). 2010.
[9] N.G. Mankiw and P. Swagel, "The politics and economics of offshore outsourcing." Journal of monetary Economics 53(5): 1027-1056. 2006.

[10] T. Callen, "What is gross domestic product." Finance \& Development 45(4): 48-49. 2008.

[11] M. Mehrara and B.A. Firouzjaee, "Granger causality relationship between export growth and GDP growth in developing countries: panel cointegration approach." International Journal of Humanities and Social Science 1(16): 223-231. 2011.

[12] Z. Xu, "On the causality between export growth and GDP growth: an empirical reinvestigation." Review of International Economics 4(2): 172-184. 1996. 